\title{
Analisis Konsumsi Daya Sepeda Motor Listrik Beroda Tiga Sebagai Pengembangan Awal Kendaraan Ramah Lingkungan untuk Penyandang Difabel
}

\author{
Rolan Siregar 1,a), Daniel Escobar Hutabarat ${ }^{2)}$, Sendi Setiawan Djabumir ${ }^{3)}$, \\ Asyari Daryus ${ }^{4)}$, Yefri Chan ${ }^{5)}$, Didik Sugiyanto ${ }^{6)}$, Husen Asbanu ${ }^{7)}$ \\ 1,2,3,4,5,6,7 Program Studi Teknik Mesin Universitas Darma Persada, \\ Jl. Taman Malaka Selatan, Jakarta Timur, Indonesia, 13450 \\ a) rolansiregar@ft.unsada.ac.id (corresponding author)
}

\begin{abstract}
Abstrak
Kendaraan ramah lingkungan yang tidak menghasilkan polusi salah satunya adalah sepeda motor listrik. Dalam artikel ini dirancang sebuah prototipe sepeda motor listrik beroda tiga untuk masyarakat difabel. Perlu dilakukan pengkajian biaya konsumsi daya listrik pada sepeda motor listrik yang dirancang ini untuk melihat gambaran perbedaan baiaya terhadap konsumsi bahan bakar minyak. Tujuan penelitian adalah untuk mengetahui jarak tempuh dan konsumsi daya baterai yang digunakan pada sepeda motor listrik yang dibuat. Metode penelitian ini adalah dengan cara eksperimental. Hasil penelitian menunjukkan bahwa jarak tempuh sepeda motor listrik tersebut adalah 19,71 km sampai daya baterai habis. Biaya listrik yang dibutuhkan sepeda motor listrik ini untuk menempuh jarak $1 \mathrm{~km}$ adalah Rp 63,26 yang jika dibandingkan dengan dengan sepeda motor (Vario 125 eSP) untuk menempuh $1 \mathrm{~km}$ adalah Rp 128,57. Sehingga dapat diberikan kesimpulan bahwa biaya daya listrik lebih rendah dibandingkan dengan biaya bahan bakar minyak. Penelitian ini merupakan tahap awal dalam perancangan sepeda motor listrik beroda tiga sehingga dibutuhkan penelitian lebih lanjut agar diperoleh kendaraan listrik yang lebih optimal dari sisi konsumsi daya listrik, serta juga memiliki sumber energi listrik tambahan supaya jarak tempuh dapat lebih jauh.
\end{abstract}

Kata kunci: green vehicle, konsumsi daya listrik, sepeda motor, sepeda motor listrik

\begin{abstract}
One of environment friendly vehicle that does not produce pollution is an electric motorcycle. In this article, a prototype of a three-wheeled electric motorcycle is designed for people with disabilities. It is necessary to study the cost of electric power consumption for the designed electric motorcycle, to see the cost difference against fuel consumption. The purpose of the study was to determine the mileage and power consumption of the battery used on the developed electric motorcycle. This research method is experimental. The results showed that the mileage of the electric motorcycle was $19.71 \mathrm{~km}$ as the

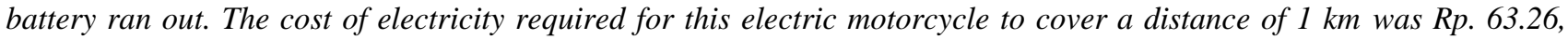
compared to the motorcycle (Vario $125 \mathrm{eSP}$ ) covering a distance of $1 \mathrm{~km}$ which was Rp. 128.57. So it can be concluded that the cost of electricity is lower than gasoline. This research is still on early stage in the design of a three-wheeled electric motorcycle, therefore further research is needed in order to obtain electric vehicle that has more optimal electric power consumption, and also has additional source of electrical energy to cover longer distances.
\end{abstract}

Keywords: electric motorcycle, electric power consumption, green vehicle, motorcycle

\section{PENDAHULUAN}

Pengembangan sepeda motor listrik merupakan salah satu upaya untuk mengurangi konsumsi bahan bakar fosil dan sekaligus mengurangi polusi udara. Telah banyak dilakukan oleh peneliti sebelumnya tentang rancang bangun kendaraan listrik, di mana tujuan utamanya adalah menciptakan kendaraan yang ramah lingkungan. Polusi udara di suatu kota besar seperti Jakarta adalah masalah yang serius sehingga perlu dilakukan berbagai perencanaan untuk mengendalikan polusi tersebut [1]. Tanggung jawab pengendalian polusi udara ini terletak pada pemerintah dan non pemerintah seperti Non Governmental Organization (NGO) untuk lingkungan [2]. Telah banyak para ahli memberikan kesimpulan terkait dengan pengurangan polusi udara yaitu melalui pembuatan kendaraan listrik. Kendaraan listrik yang tidak menggunakan motor bakar sudah tentu tidak menghasilkan asap, sehingga sering disebut emisi zero [3], [4].

Berbagai jenis kendaraan listrik perlu dianalisis dengan rinci sehingga dapat menjadi teori dalam meningkatkan kualitas jenis kendaraan tersebut [5]. Dengan alasan mengurangi ketergantungan terhadap produk luar negeri maka Indonesia sebaiknya perlu membuat kendaraan listrik dengan teknologi sendiri dan dengan bahan baku dari domestik. Penelitian tentang rancang bangun produk dalam negeri idealnya didukung oleh semua pihak baik pemerintah ataupun swasta. Pada akhirnya hasil penelitian itu dapat diterapkan oleh pihak yang membutuhkan untuk 
menciptakan produk tersebut seperti kendaraan sepeda motor listrik beroda tiga.

Sepeda motor listrik beroda tiga ini sangat berguna untuk kalangan disabilitas karena kemudahan operasional. Sepeda listrik sebagai alat bantu transportasi bagi penyandang difabel sangat bermanfaat untuk mendukung aktifitasnya. Motor listrik memperoleh energi dari baterai lalu dikonversi menjadi energi mekanik [6], artinya sistem mekanikal berpengaruh terhadap konsumsi daya. Sistem mekanikal yang telah dirancang dalam artikel ini tentu berbeda dengan sistem mekanikal pada produk lain, sehingga memiliki karakter konsumsi daya yang berbeda juga. Dari produk yang dibuat perlu ditampilkan karakterisasi konsumsi daya. Penelitian yang dilakukan oleh (Dahlan dkk, 2018) [6] menampilkan pengujian konsumsi daya sepeda motor listrik roda dua yang bertujuan untuk menampilkan performa kendaraan berupa jarak tempuh dan karakteristik arus dan tegangan pada waktu tertentu beserta jumlah daya yang dikonsumsi dalam satu perjalanan tertentu. Pada pengujian tersebut belum menampilkan perbandingan harga daya listrik dengan harga gasoline pada jarak tempuh yang sama. Oleh karena itu pada penelitian ini dilakukan pengujian konsumsi daya listrik pada kendaraan yang dirancang dengan spesifikasi geometri dan bentuk desain yang dibuat sendiri, hal ini bermanfaat untuk mengetahui karakter kendaraan tersebut sehingga diperoleh informasi kelemahan dan kelebihan produk tersebut.

Guna mendapatkan suatu produk yang optimal tentu ada suatu masalah sehingga perlu dilakukan analisis dalam menyelesaikan masalah tersebut. Seperti pada topik penelitian ini, akan timbul pertanyaan yaitu apakah sepeda motor listrik dengan sumber daya baterai mampu menempuh jarak relatif jauh sesuai dengan kebutuhan para difabel, dan seberapa besar biaya yang akan dikeluarkan untuk mengisi daya listrik baterai. Dalam hal ini biaya mengisi daya listrik apakah seimbang dengan biaya dalam mengisi bahan bakar minyak. Sehingga tujuan khusus penelitian ini adalah untuk mengetahui jarak tempuh dan konsumsi daya baterai yang digunakan pada sepeda motor listrik yang digunakan. Sepeda motor listrik ini diperkirakan bisa menjadi solusi alternatif sebagai kendaraan yang sesuai untuk kaum difabel dalam melaksanakan aktifitasnya.

\section{LANDASAN TEORI}

A. Pengenalan bahan bakar fosil, polusi, dan kendaraan listrik

Sudah menjadi pengetahuan umum bahwa ketersediaan bahan bakar fosil yang ada di Indonesia akan terus menurun dan pada saat tertentu tidak mencukupi kebutuhan masyarakat Indonesia. Jumlah pertumbuhan penduduk berbanding lurus terhadap kebutuhan pokok bahan bakar minyak di Indonesia [7]. Menurut (Sa'adah, Fauzi, \& Juanda, 2017) [8] menyatakan bahwa tahun 2017 sampai 2025, penyediaan BBM tidak dapat memenuhi kebutuhan BBM dalam negeri. Hal ini dikarenakan konsumsi BBM lebih tinggi dari penyediaan BBM tersebut. Dilain sisi menurut tim peneliti (Braithwaite \& Gerasimchuk, 2019) [9] dalam laporan Selepas Bahan
Bakar Fosil: Transisi Fiskal Indonesia menyatakan bahwa pendapatan Indonesia sangat besar dari pajak penjualan bahan bakar fosil. Oleh karena itu apabila pada saat tertentu BBM sudah menurun maka Indonesia sebaiknya harus mencari alternatif dalam memenuhi pendapatan negara. Salah satu solusi alternatif adalah dengan mengembangkan produksi produk dalam negeri.

Penggunaan bahan bakar minyak berkaitan dengan hasil gas buang di mana gas ini sebagian memiliki unsur yang tidak cocok untuk kesehatan manusia. Dalam makalah yang dibuat oleh (Ismiyati, Marlita, \& Saidah, 2014) [10] menampilkan bahwa polusi di Indonesia perlu dilakukan penanganan serius dengan berbagai cara seperti pengurangan kendaraan bermotor pribadi menjadi kendaraan transportasi publik. Selanjutnya (Handika \& Driejana, 2013) [11] menggambarkan tentang bahaya polusi udara dari kendaraan bagi penghuni rumah yang ada di pinggir jalan raya.

Dari berbagai masalah tentang konsumsi bahan bakar dan polusi gas buang motor bakar maka berbagai negara berlomba dalam mencari solusi untuk menyelesaikan masalah tersebut. Salah satu alternatif adalah dengan mengadakan kendaraan listrik. Menurut (Kumara, 2008) [12] perkembangan kendaraan listrik mengalami pasang surut yang dipicu oleh fluktuasi suplai minyak dunia.

Keterbatasan cadangan sumber energi konvensional serta dampak pemakaianya terhadap lingkungan merupakan faktor-faktor utama berkembangnya teknologi kendaraan listrik. Sekarang ini, fenomena pemanasan global sudah semakin dipahami yang menuntut upaya manusia untuk secara nyata mengurangi emisi karbon ke dalam atmosfir bumi. Kemudian, isu keterbatasan cadangan sumber daya alam sudah melewati batas geografis dan politik sebuah negara dimana sudah mengacu kepada prinsip sumber daya planet bumi secara keseluruhan. Bahwa cadangan sumber daya alam di perut planet bumi jumlahnya terbatas untuk itu manusia perlu menggunakanya secara arif. Kendaraan listrik merupakan salah satu solusi yang sangat penting dalam upaya penyelamatan lingkungan dan pengelolaan sumber alam secara berkelanjutan.

\section{B. Proses pengembangan produk}

Proses pengembangan produk atau sering dikenal dengan Product Development Process (PDP) secara sederhana dapat diartikan sebagai suatu tahapan yang sistematis untuk menciptkan model baru yang memiliki kelebihan tertentu di mana model ini dikembangkan dari produk yang sudah ada. Menurut (Dieter \& Schmidt, 2013) [13] dalam bukunya engineering design menyatakan bahwa ada enam fase atau tahapan dalam proses pengembangan produk. Adapun tahapan tersebut ditunjukkan pada gambar 1 .

Phase 0 merupakan tahapan pendahuluan berupa planning (perencanaan). Phase 0 ini menjelaskan tentang kematangan rencana sebelum pemilihan objek yang akan dikembangkan dimulai. Faktor kebutuhan konsumen yang selalu ingin yang terbaik merupakan awal dari projek pengembangan produk dimulai.

Phase 1 (tahapan 1) menyatakan pengembangan konsep 
(concept development), bagian ini merupakan proses dalam mempertimbangkan bagian yang paling memungkinkan untuk dikembangkan, seperti subsistem

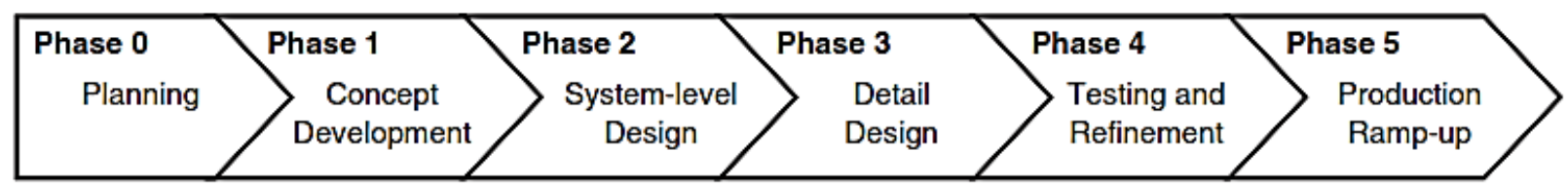

Gambar 1. Tahapan pengembangan produk [13].

produk, atau secara keseluruhan. Tim pengembang harus mampu menangkap bagian apa saja yang dibutuhkan oleh konsumen untuk dikembangkan sehingga konsumen puas. Pada bagian ini sudah mulai memasuki pembahasan Product Design Specification (PDS).

Phase 2 tentang system level design, pada bagian ini mempelajari fungsi suatu produk dengan rinci termasuk ke subsistem produk. Apabila sudah dipahami semua maka bentuk poduk dan spesifikasi produk sudah ditentukan sehingga kebaruan produk sudah diperoleh.

Phase 3 tentang detail design, pada fase ini sudah memasuki deskripsi teknik yang lengkap di mana produk telah dipastikan dapat untuk diproduksi. Oleh karena itu dalam bagian ini telah dilakukan perhitungan teknik yang rinci[14] dan penyajian gambar teknik yang lengkap.

Phase 4 tentang Testing and Refinement, pada bagian ini terdapat pengujian produk dan penyempurnaan produk sampel. Hal ini dilakukan untuk memastikan produk siap diproduksi massal. Sistem produksi/cara-cara produksi yang terbaik, dilakukan di tahap ini, untuk memperoleh proses manufaktur yang paling efektif.

Phase 5 tentang Production Ramp-up, pada bagian ini operasi manufaktur sudah mulai dilakukan dan merakit produk menggunakan sistem produksi yang telah dibahas pada fase -fase sebelumnya.

\section{Gambaran umum sepeda motor listrik}

Sebagai gambaran umum model sepeda motor listrik ditunjukkan pada gambar 2 .

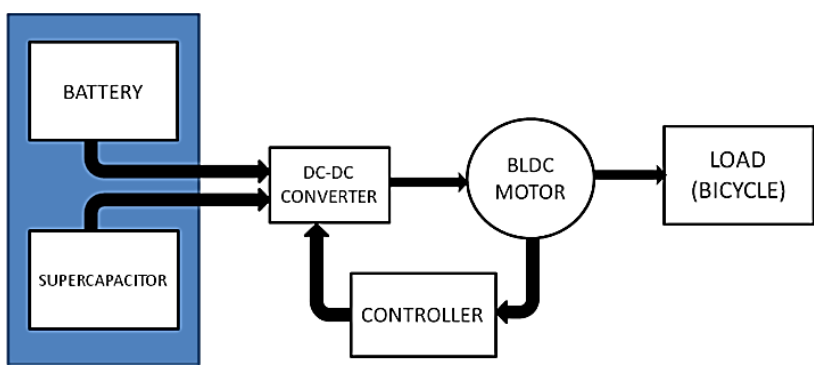

Gambar 2. Diagram blok sepeda motor listrik [15]

Secara umum sepeda listrik bergerak akibat adanya daya dan torsi yang dihasilkan oleh motor. Kecepatan motor dapat dikendalikan dengan menggunakan sebuah kontroler motor tersebut. Motor berkerja dengan mengubah energi listrik menjadi energi mekanik, di mana energi listrik ini diperoleh dari komponen baterai.

\section{Baterai}

Baterai adalah media untuk menyimpan energi listrik, Secara umum berdasarkan proses baterai dapat dibagi menjadi dua bagian yaitu primary battery dan secondary battery. Primary battery dapat diartikan sebagai baterai yang hanya dapat digunakan sekali pakai apabila kapasitas energinya telah habis, sedangkan secondary battery adalah adalah baterai yang dapat diisi ulang apabila kapasitas energi telah habis. Adapun contoh primary battery adalah baterai zinc-carbon, alkaline, silver oxide, dan lain-lain. Contoh battery secondary lithium-ion (Li-ion atau LIB), Lithium Polymer (Li-Po), Baterai Lead Acid (Accu) dan Nickel-Metal Hydride (Ni-MH). Karakter baterai yang cocok untuk kendaraan listrik yaitu memiliki kepadatan energi yang tinggi, ringan, dan tahan terhadap temperatur tinggi [16]. Pada saat ini jenis baterai litihium-ion merupakan tipe baterai yang banyak digunakan dalam kendaraan listrik, berbagai upaya dilakukan oleh berbagai peneliti untuk mendapatkan formula baterai lithium ion yang memiliki efisiensi tinggi [16][17]. Pada umumnya diagram blok sistem baterai dalam kendaraan listrik ditunjukkan pada gambar 3. Manajemen penggunaan baterai sangat berpengaruh terhadap penghematan daya listrik.

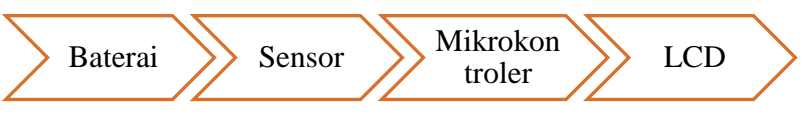

Gambar 3. Diagram blok sistem baterai [18]

\section{E. Kapasitas baterai}

Kapasitas baterai dapat diartikan sebagai kemampuan baterai dalam menyimpan daya listrik dan mengeluarkan daya listrik tersebut. Kapasitas energi suatu baterai dapat dinyatakan dalam ampere jam (Ah), besar kecilnya tegangan baterai ditentukan oleh banyak sedikitnya sel baterai yang ada di dalamnya[19]. Arus dapat mengalir bila ada konduktor dan beban yang dihubungkan ke baterai tersebut. Kapasitas baterai menunjukan kemampuan baterai untuk mengeluarkan arus (discharging) selama waktu tertentu. Pada saat baterai diisi (charging), maka akan terjadi penimbunan muatan listrik. Jumlah maksimum muatan listrik yang dapat ditampung oleh baterai disebut kapasitas baterai dan dinyatakan dalam ampere jam (Ampere hour) [19]. Kapasitas baterai dapat dinyatakan dengan persamaan 1 berikut: 
$N=I \cdot t$

di mana:

$$
\begin{aligned}
\mathrm{N} & =\text { Kapasitas baterai }(A h) \\
\mathrm{I} & =\text { Kuat arus }(A) \\
\mathrm{t} & =\text { Waktu }(\mathrm{jam} / \text { second })
\end{aligned}
$$

\section{F. Charger baterai}

Charger baterai digunakan untuk mengisi ulang daya baterai dari sumber listrik. Biasanya sumber arus listrik yang digunakan untuk mencharger baterai adalah listrik AC (Alternating Current). Untuk mengubah arus AC ke arus DC (Direct Current) digunakan converter arus AC/DC. Converter ini bekerja untuk menyesuaikan arus yang masuk ke baterai. Charger baterai ini memiliki charge controler yang berfungsi untuk mengontrol arus sesuai kebutuhan BMS (Battery Management System). Bilamana kapasitas baterai sudah terpenuhi maka kontrol charger akan bekerja sehingga arus masuk dapat berhenti.

\section{G. Motor listrik}

Sebagai pengganti motor bakar adalah motor listrik. Motor listrik memiliki arti sebagai alat untuk mengubah energi listrik menjadi energi mekanik. Berbeda dengan dinamo yang dapat mengubah energi mekanik menjadi energi listrik. Motor DC ataupun motor AC telah digunakan di berbagai jenis kendaraan listrik, tentu memiliki kelebihan dan kelemahan masing-masing. Motor DC memiliki kelemahan dari sisi perawatan namun lebih mudah dalam hal pengontrolan motor tersebut. Sesuai perkembangannya motor AC telah mulai banyak digunakan untuk kendaraan listrik karena berbagai kelebihan yaitu berat yang lebih ringan pada spesifikasi daya yang setara, dapat didesain untuk kebutuhan daya yang tinggi. Pada sepeda, dinamo biasanya digunakan untuk menghasilkan energi listrik dari gerakan roda, energi listrik biasa digunakan untuk penerangan. Pada saat ini motor listrik sedang banyak digunakan untuk membantu gerak sepeda dari ayunan manual.

Energi listrik dilambangkan dengan W. Sedangkan perumusan yang digunakan untuk menentukan besar energi listrik ditunjukkan pada persamaan 2:

$$
W=Q \cdot V
$$

$$
\text { di mana: }
$$

$$
\begin{aligned}
\mathrm{W} & =\text { Energi listrik (Joule) } \\
\mathrm{Q} & =\text { Muatan listrik (Coulumb) } \\
\mathrm{V} & =\text { Beda potensial (Volt) }
\end{aligned}
$$

Energi yang tersimpan dalam arus listrik dengan satuan amper (A) dan tegangan listrik dengan satuan volt (V) dengan ketentuan kebutuhan konsumsi daya listrik dengan satuan watt (W) [20]. Dalam menentukan motor listrik sesuai dengan kebutuhan jenis kendaraan yang dirancang dapat dihitung dari segi torsi yang dibutuhkan. Perhitungan torsi motor listrik menggunakan persamaan 3 berikut:

$$
\begin{aligned}
& T_{\text {Motor }}=\frac{60 \cdot P}{2 \cdot \pi \cdot n} \\
& \text { Di mana: } \\
& P \quad=\text { Daya motor }(W) \\
& n \quad=\text { Putaran poros motor }(R P M) .
\end{aligned}
$$

\section{H. Sistem power train}

Power train diartikan sebagai sistem yang bersinergi untuk meneruskan tenaga dari motor listrik (motor bakar) sampai ke penggerak akhir. Pada setiap elemen power train akan mengalami perubahan torsi atau putaran sehingga dilakukan perhitungan yang tepat supaya torsi yang sampai ke roda sebagai pengerak akhir sesuai dengan rancangan awal. Spesifikasi kendaraan listrik yang ditinjau pada kasus ini adalah kendaraan listrik tipe sepeda motor listrik beroda tiga yang dapat digunakan oleh kalangan difabel. Sepeda motor beroda tiga sering disebut dengan trike. Trike artinya memiliki tiga buah roda yaitu dua buah roda didepan dan satu buah roda dibelakang atau sebaliknya. Maka jika penggerak kendaraan tersebut adalah motor listrik maka sepeda tersebut dapat diartikan sebagai electric trike. Electric trike ini relatif lebih mudah untuk dikendarai dan lebih ramah lingkungan karena lebih stabil, suaranya yang sangat halus, dan perawatan yang lebih mudah. Kemudahan dikendarai karena memiliki tiga tumpuan ke ground sehingga lebih stabil dari kendaraan roda dua. Suara yang lebih halus tentu kebisingan motor listrik lebih kecil daripada motor bakar, terkait dengan ramah lingkungan maka sepeda motor listrik beroda tiga ini adalah emisi zero karena dia tidak menggunakan bahan bakar minyak. Guna perjalanan jarak dekat kendaraan ini sangat disarankan untuk digunakan.

Motor listrik sebagai penggerak dapat ditempatkan di as roda depan (apabila dirancang sebagai kendaraan penggerak depan), as roda belakang (apabila dirancang sebagai kendaraan penggerak belakang), dan terpisah dari as roda sehingga dibutuhkan sistem power train.

Pada saat kendaraan berjalan akan terjadi beberapa gaya hambat yang dapat menghambat laju kendaraan dan pada akhirnya akan dapat meningkatkan konsumsi energi listrik. Secara umum ada 3 gaya hambat utama pada saat kendaraan yaitu gaya hambat guling (rolling resistance), gaya hambat angin (aerodynamic resistance), dan gaya hambat tanjakan (grade resistance) [21].Tahanan gelinding (rolling resistance) adalah tahanan yang terjadi pada roda kendaraan diatas permukaan tanah. Saat kendaraan bergerak partikel udara akan menumbuk permukaan kendaraan sehingga menimbulkan hambatan pada laju kendaraan. Kemiringan jalan akan mempengaruhi hambatan gerak jalan kendaraan sehingga perlu dilakukan perhitungan yang maksimum.

\section{METODE PENELITIAN}

Metode yang digunakan dalam penelitian ini adalah metode ekperimental. Sebagai tahap awal dilakukan review literature sepeda listrik, desain mekanik, perakitan, dan pengujian konsumsi daya. Perhitungan dilakukan untuk mendapatkan ukuran yang optimal sehingga diperoleh performa gerak kendaraan yang efisien. Setelah perhitungan elemen penyusun dan ukuran sudah selesai 
lalu dibuatlah desain teknik berupa gambar teknik berbasis Computer Aided Design (CAD). Software CAD yang digunakan adalah Autodesk Inventor versi student. Gambar berbasis CAD memiliki kelebihan yaitu efisien dan mudah melakukan revisi bentuk. Selain membuat gambar teknik software berbasis $C A D$ seperti Autodesk Inventor telah dapat digunakan untuk melakukan simulasi numerik seperti analisis kekuatan struktur, sehingga optimalisasi ukuran dapat diperoleh [22], [23].

Tahapan pelaksanaan penelitian ditampilkan dalam diagram alir pada Gambar 4. Gambar sepeda listrik dibuat dengan memperkirakan kemampuan biaya produksi dan batas waktu dalam melakukan penelitian ini. Sehingga bentuk sepeda listrik dibuat sederhana. Sepeda yang dibuat adalah sepeda motor listrik beroda tiga. Di mana sepeda ini dikategorikan kendaraan yang stabil dan relatif mudah dikendarai sehingga cocok sebagai alat bantu transportasi untuk orang difabel cacat kaki. Desain yang sederhana menunjukkan untuk kemudahan pembuatannya supaya pihak pihak yang membutuhkan dapat dengan mudah menciptakan produk ini. Diawali dengan membuat dua buah sketsa desain produk lalu kemudian dilakukan pemilihan desain terbaik.

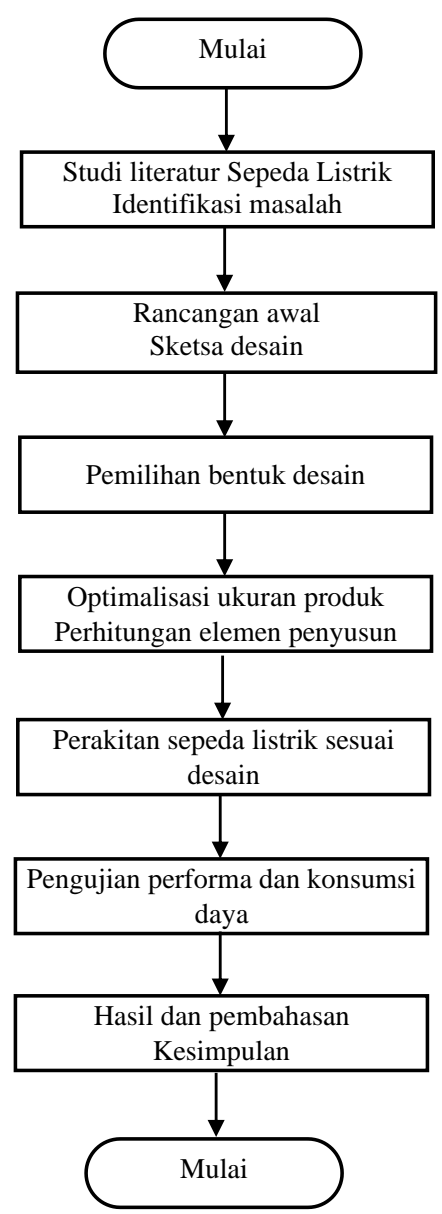

Gambar 4. Tahapan pelaksanaan penelitian

Gambar 5 menunjukkan dua buah pilihan sketsa awal produk.

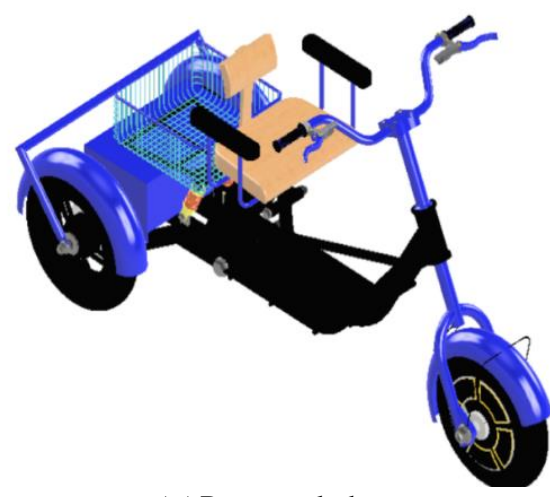

(a) Penggerak depan

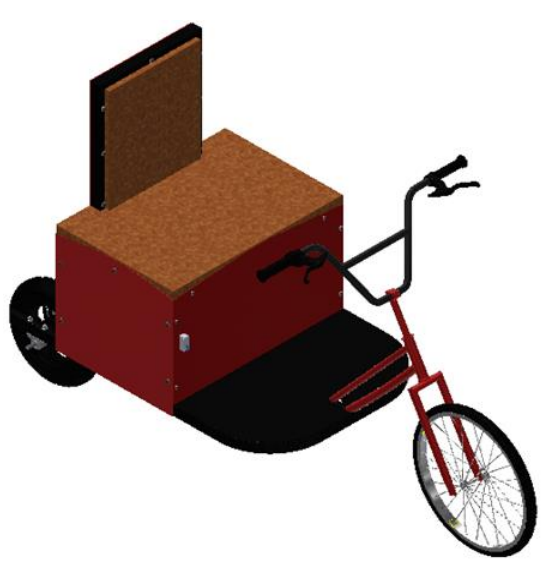

(b) Penggerak belakang

Gambar 5. Sketsa desain sepeda motor listrik: $a$ - penggerak depan; $b$ - Penggerak belakang

Setelah sketsa desain diperoleh lalu dilakukan pemilihan satu buah desain terbaik. Pemilhan tersebut dapat dilakukan dengan metode perbandingan penilaian terhadap faktor faktor yang berkaitan dengan optimasi produk. Tabel 1 menunjukkan tabel pemilihan desain terbaik.

Tabel 1. Penilaian dalam pemilihan desain terbaik

\begin{tabular}{|c|c|c|c|c|c|}
\hline \multirow[b]{2}{*}{ Item } & \multirow{2}{*}{$\begin{array}{c}\text { Penilaian } \\
(\%)\end{array}$} & \multicolumn{2}{|c|}{ Desain A } & \multicolumn{2}{|c|}{ Desain B } \\
\hline & & Nilai & Persentasi & Nilai & Persentasi \\
\hline $\begin{array}{l}\text { Harga } \\
\text { Bahan } \\
\end{array}$ & 40 & 1 & 0,4 & 3 & 1,2 \\
\hline Manufaktur & 20 & 1 & 0,2 & 2 & 0,4 \\
\hline Maintenance & 10 & 3 & 0,3 & 3 & 0,3 \\
\hline $\begin{array}{l}\text { Performa } \\
\text { produk }\end{array}$ & 30 & 2 & 0,6 & 2 & 0,6 \\
\hline Score & 100 & & 1,5 & & 2,5 \\
\hline
\end{tabular}

Keterangan nilai dibuat dari angka 1 s.d. 3 di mana angka 1 adalah mahal/high, angka 2 adalah cukup mahal/ medium, dan angka 3 adalah murah/low. Angka yang tinggi adalah penilaian terbaik, maka akumulasi nilai yang 
terbesar adalah desain produk terbaik. Maka berdasarkan Tabel 1 dapat dilihat bahwa desain A memiliki score 1,5 sedangkan desain B memiliki score 2,5. Maka dari itu dapat dipilih desain B karena memiliki score tertinggi secara otomatis akan dilanjutkan untuk proses pabrikasi dan perakitan.

Elemen utama atau sub-assembly dari desain B terdiri atas rangka floor, rangka bangku, rangka dudukan motor, rangka siku stang, dan sistem powertrain. Elemen-elemen utama tersebut ditunjukkan pada tabel 2 .

Tabel 2. Komponen utama sepeda motor listrik

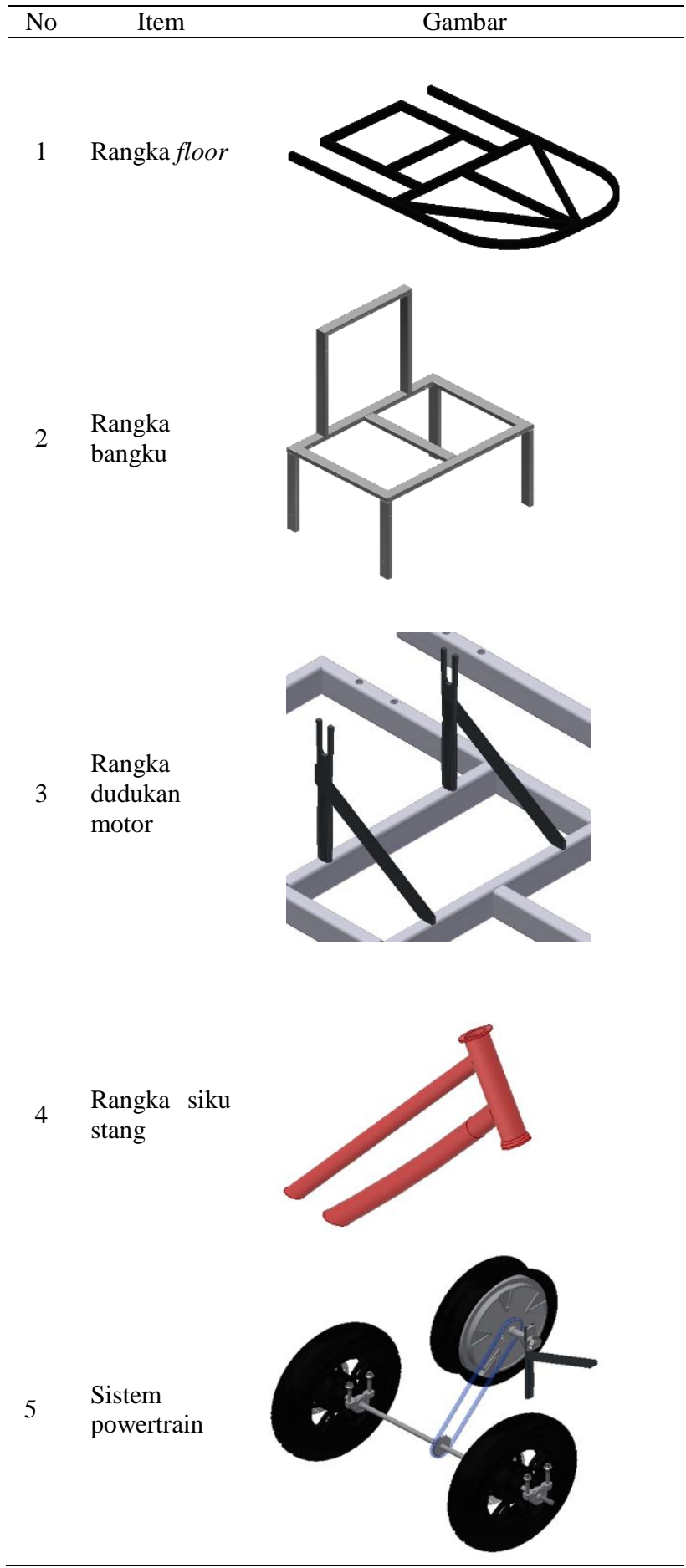

Rangka adalah bagian utama yang menjadi perhatian karena rangka ini merupakan tempat mounting semua elemen penyusun dan juga berkaitan dengan panjang, lebar, dan tinggi kendaraan. Rangka tersebut didesain terlebih dahulu dalam bentuk CAD lalu dilakukan analisa sehingga rangka tersebut memungkinkan untuk diproduksi. Adapun dalam Gambar 6 ditampilkan bentuk rangka sepeda motor listrik beroda tiga.

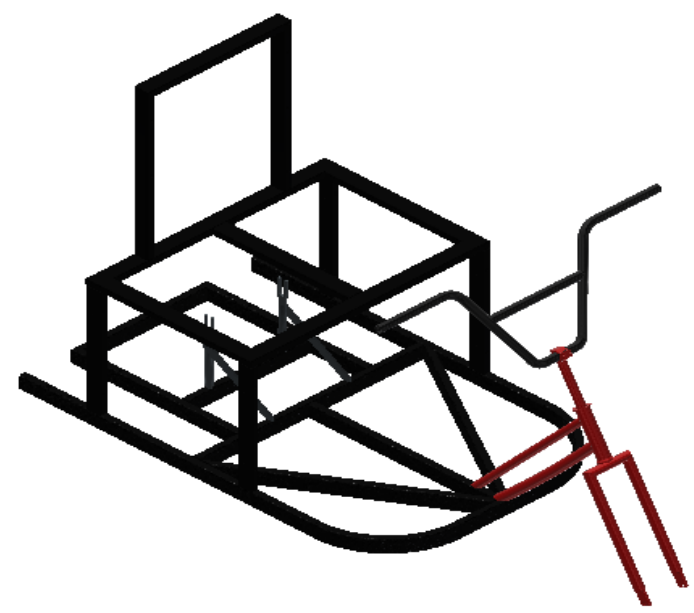

Gambar 6. Rangka utama sepeda motor listrik beroda tiga

Rangka atau chasis sepeda motor tiga listrik ini dibuat dengan bentuk yang relatif mudah diproduksi. Setelah rangka struktur diperoleh maka dilakukan simulasi deformasi dan tegangan struktur untuk mengetahui kalayakan struktur dengan material yang telah dipilih. Simulasi struktur mekanikal dilakukan dengan basis metode elemen hingga yang telah ada dalam software Computer Aided Engineering (CAE) seperti Autodesk Inventor ${ }^{\mathrm{TM}}$. Bentuk simulasi deformasi ditunjukkan pada gambar 7 .

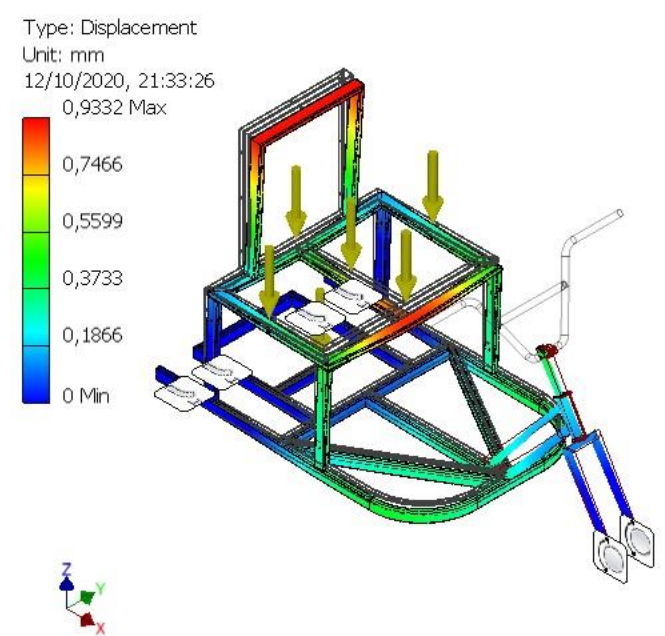

Gambar 7. Simulasi deformasi struktur rangka

Berdasarkan hasil simulasi tersebut dapat ditampilkan bahwa besar deformasi maksimum adalah $0,9332 \mathrm{~mm}$ akibat pembebanan maksimum. Simulasi deformasi dilakukan untuk mengetahui posisi defleksi terbesar yang 
terjadi pada kendaraan apabila diberikan pembebanan maksimum. Deformasi maksimum juga digunakan sebagai bahan pertimbangan dalam menentukan desain struktur dan jenis material penyusun struktur tersebut. Bentuk desain dan jenis material yang efisien akan menghasilkan produk yang lebih optimal. Selanjutnya simulasi tegangan pada struktur rangka dapat ditunjukkan pada gambar 8 .

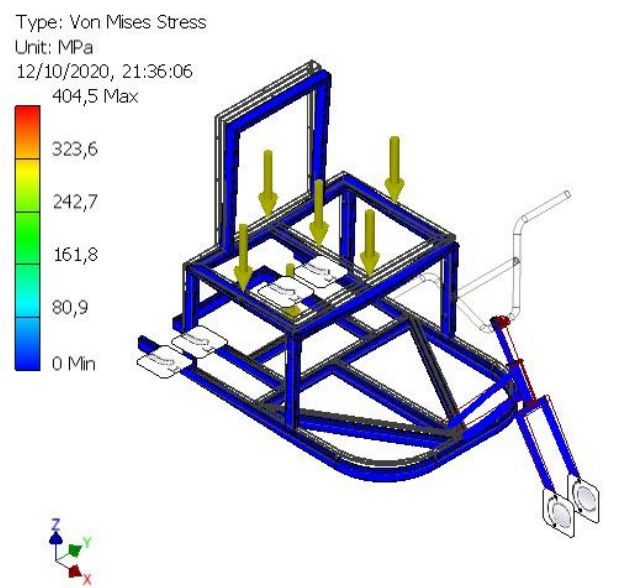

Gambar 8. Simulasi tegangan pada frame

Besar tegangan maksimum yang diperoleh dalam simulasi ini adalah 404,5 $\mathrm{MPa}$, oleh karena itu material yang digunakan dalam struktur tersebut harus mampu menahan tegangan maksimum tersebut. Secara keseluruhan komponen rangka dibuat dengan bentuk yang mudah dimanufaktur. komponen kelistrikan seperti baterai, kontrol motor, dan manajemen baterai diletakkan didalam konstruksi tempat duduk. Elemen penyusun seperti baterai, motor, dan kontroler, merupakan bagian yang dipilih berdasarkan perhitungan kebutuhan untuk spesifikasi desain yang dipilih. Gambar 9 menunjukkan desain sepeda listrik dalam bentuk CAD.

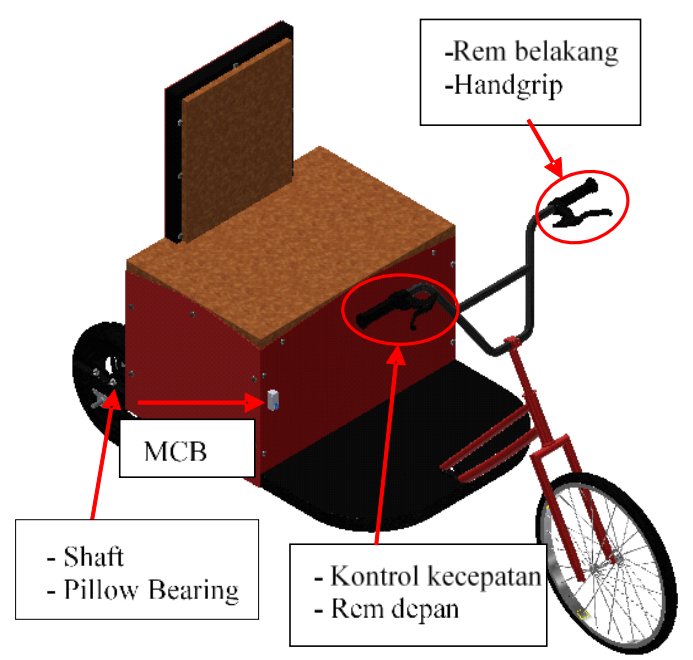

Gambar 9. Desain sepeda motor listrik 3 roda

Gambar 9 menunjukkan elemen-elemen utama penyusun sepeda listrik yaitu kontrol kecepatan motor untuk mengatur kecepatan dalam menjalankan sepeda listrik, rem depan (berada pada bagian atas ban seperti sepeda biasa) dan rem belakang (berada pada bagian belakang dan terhubung langsung dengan dinamo motor listrik) untuk menghentikan atau memperlambat kendaraan pada posisi berjalan, MCB untuk mematikan dan menghidupkan motor listrik yang terhubung langsung dengan controller dan kutub positif pada aki. Shaft digunakan sebagai penghubung antara ban kiri dan kanan yang digerakan langsung oleh dinamo motor listrik yang dihubungkan dengan menggunakan rantai, pillow bearing digunakan sebagai penahan shaft yang berada dibawah rangka sehingga memudahkan dalam melakukan perbaikan ketika ban yang digunakan ingin diganti ataupun diperbaiki.

Pada setiap konstruksi rangka dibuat gambar detail teknik dimana desain yang sudah rinci dapat dilanjutkan ke tahapan pabrikasi, lalu perakitan dan diakhiri dengan pengujian performa daya baterai yang digunakan. Efisiensi daya baterai berkaitan dengan bentuk yang didesain tersebut. Bilamana desain optimal akan menghasilkan dinamika gerak yang sesuai sehingga kendaraan dapat bergerak dengan mudah, dan daya yang dibutuhkan untuk kendaraan tersebut lebih kecil. Keterkaitan semua elemen penyusun adalah hal yang harus diperhitungkan dengan baik untuk performa kerja produk tersebut.

\section{HASIL DAN PEMBAHASAN}

Setelah desain produk sudah rinci maka pabrikasi dapat dilakukan. Gambar 10 menunjukkan bentuk sepeda motor listrik beroda tiga.

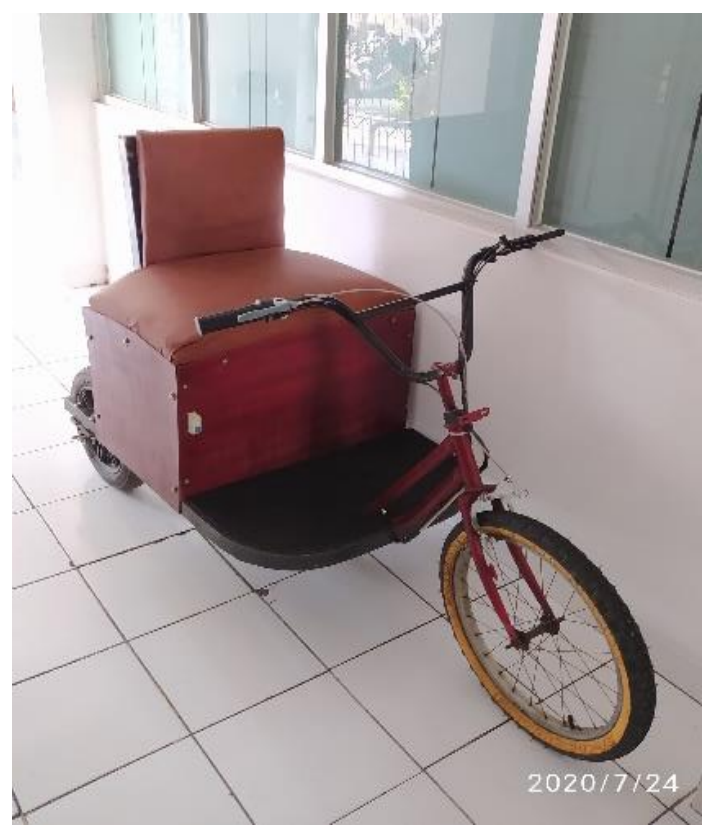

Gambar 10. Hasil perakitan sepeda motor listrik beroda tiga

Sedangkan tabel 3 menunjukkan spesifikasi produk yang ditunjukkan pada gambar 10 . 
Tabel 3. Spesifikasi sepeda motor listrik beroda tiga

\begin{tabular}{clcc}
\hline No & \multicolumn{1}{c}{ Item } & Nilai & Satuan \\
\hline A & Dimesi utama kendaraan & & \\
1. & Wheel base & 1328 & $\mathrm{~mm}$ \\
2. & Overall Width & 700 & $\mathrm{~mm}$ \\
3. & Overall Heigh & 1020 & $\mathrm{~mm}$ \\
B & Performa kendaraan & & \\
4. & V & 25 & $\mathrm{~km} / \mathrm{h}$ \\
5. & Kapasitas angkut & 90 & $\mathrm{~kg}$ \\
C. & Penumpang & & \\
6. & Daya Maksimum & 350 & $\mathrm{Watt}$ \\
7. & Torsi Maksimum & 500 & $\mathrm{Nm}$ \\
\hline
\end{tabular}

Ukuran produk ini dirancang untuk rata-rata postur badan orang Indonesia. Kecepatan maksimum dibuat 25 $\mathrm{km} / \mathrm{jam}$ untuk memenuhi kendaraan lambat bukan untuk kendaraan umum seperti sepeda motor bakar yang memiliki surat tanda nomor kendaraan (STNK). Adapun kapasitas angkut kendaraan idealnya tidak melebihi $90 \mathrm{~kg}$, akan tetapi dengan adanya safety faktor kendaraan masih dapat mengangkut sampai $120 \mathrm{~kg}$. Selanjutnya spesifikasi dari motor listrik beroda tiga ditunjukkan pada tabel.

Tabel 4. Spesifikasi motor

\begin{tabular}{ll}
\hline Item & Satuan \\
\hline Tegangan & $48 \mathrm{~V}$ \\
Power & 350 Watt \\
Ampere kerja & $16-18 \mathrm{~A}$ \\
Torsi & $18-25 \mathrm{Nm}$ \\
Baterai & $12 \mathrm{v} 12 \mathrm{Ah}(4 \mathrm{Pcs})$ \\
\hline
\end{tabular}

Jenis motor yang digunakan adalah motor BLDC dengan tegangan $48 \mathrm{~V}$, daya $350 \mathrm{~W}$, Ampere 16-18 A, torsi 18-25 Nm, dan baterai 12 Ah sebanyak 4 pieces. Pengujian ketahanan baterai dilakukan dengan pengujian jalan kendaraan di wilayah lingkungan Universitas Darma Persada dengan bentuk permukaan jalan adalah jalan datar yang terbuat dari paving block.. Berat kendaraan sama dengan $64,8 \mathrm{~kg}$ ditambah berat pengemudi $61 \mathrm{~kg}$ sehingga berat secara keseluruhan $125,8 \mathrm{~kg}$, dalam penelitian ini tidak menampilkan korelasi antara berat kendaraan dengan konsumsi energi listrik. Mekanisme pengujian dilakukan dengan kecepatan konstan dan mengelilingi rute yang sama sampai baterai habis di mana sebelum dimulai uji jalan, baterai masih penuh di mana jenis baterai yang digunakan adalah baterai kering. Gambar 11 menunjukkan jelajah tempuh di lingkungan Universitas Darma Persada.

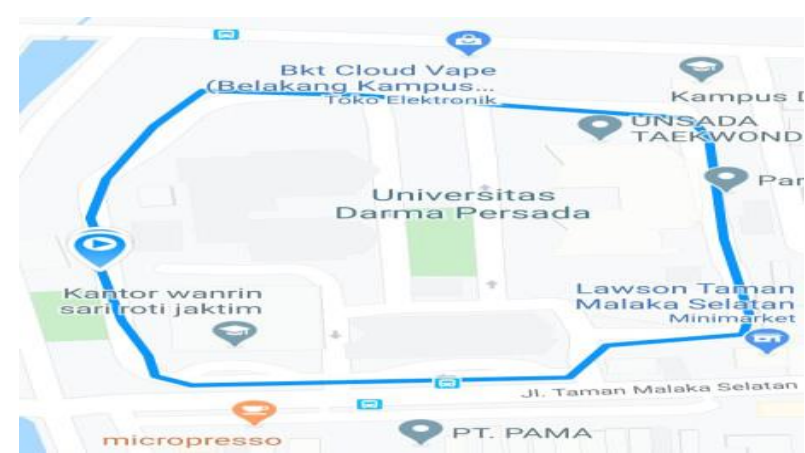

Gambar 11. Daerah jelajah yang direkam GPS tracker

Berdasarkan pengujian tersebut jarak tempuh sepeda motor listrik yang dapat dicapai adalah 19,71 km dengan waktu yang dibutuhkan 2 jam 28 menit (daya baterai sampai habis).

Selanjutnya dilakukan perhitungan biaya arus listrik yang dibutuhkan untuk mencapai 19,71 km dengan waktu tempuh 2 jam 28 menit, dan menghitung biaya yang dibutuhkan untuk kendaraan bermotor gasoline untuk menempuh jarak yang sama $(19,71 \mathrm{~km})$. Kendaraan bermotor gasoline yang ditinjau adalah salah satu jenis kendaraan (Vario 125 eSP) dengan spesifikasi konsumsi bahan bakar 59,5 km/liter [24]. Harga listrik per $\mathrm{kWh}$ yang digunakan adalah jenis listrik rumahan dengan tegangan 1300 Watt dengan biaya Rp $1.444,7$ per kWh [25]. Pada Tabel 5 dapat dilihat perbandingan harga biaya listrik dan harga gasoline untuk menempuh $19,71 \mathrm{~km}$.

Tabel 5. Perbandingan harga antara gasoline dengan biaya charge listrik untuk menempuh $19,71 \mathrm{~km}$.

\begin{tabular}{ll}
\hline Item & Harga \\
\hline Biaya charge listrik & Rp 1.246,92 \\
Gasoline & Rp 2.534,14 \\
\hline
\end{tabular}

Berdasarkan Tabel 5 dapat dilihat bahwa biaya daya listrik untuk menempuh 19,71 km adalah Rp 1.246,92 sedangkan biaya gasoline untuk menempuh jarak 19,71 $\mathrm{km}$ adalah Rp 2.562,30 (asumsi gasoline yang digunakan pertalite Rp 7.650). Pendekatan perhitungan biaya listrik dihitung dari daya motor listrik yang digunakan $350 \mathrm{~W}$ $(0,350 \mathrm{~kW})$, dan waktu yang dibutuhkan untuk menempuh $19,71 \mathrm{~km}$ adalah 2 jam 28 menit (2,466 jam), harga listrik per kWh adalah Rp 1.444,7. Maka total harga listrik adalah daya motor listrik $(0,350 \mathrm{~kW})$ dikali waktu tempuh $(2,466$ jam) dikali harga listrik per kWh Rp 1.444,7 sama dengan Rp 1.246,92. Sedangkan pendekatan perhitungan biaya gasoline untuk menempuh 19,71 km adalah dengan meninjau jarak tempuh kendaraan motor bakar (Vario 125 $e S P$ ) dalam satu liter gasoline (pertalite $\mathrm{Rp} 7.650$ ) adalah $59,5 \mathrm{~km}$, sehingga harga per $\mathrm{km}$ adalah Rp 128,57 dan untuk 19,71 km sama dengan Rp 2.534,14. Maka dapat diartikan bahwa biaya daya listrik lebih murah dibandingkan dengan biaya gasoline. Biaya listrik untuk 1 $\mathrm{km}$ adalah Rp 63,26 sedangkan biaya gasoline untuk $1 \mathrm{~km}$ adalah Rp 128,57, seperti ditunjukkan pada gambar 12 . 


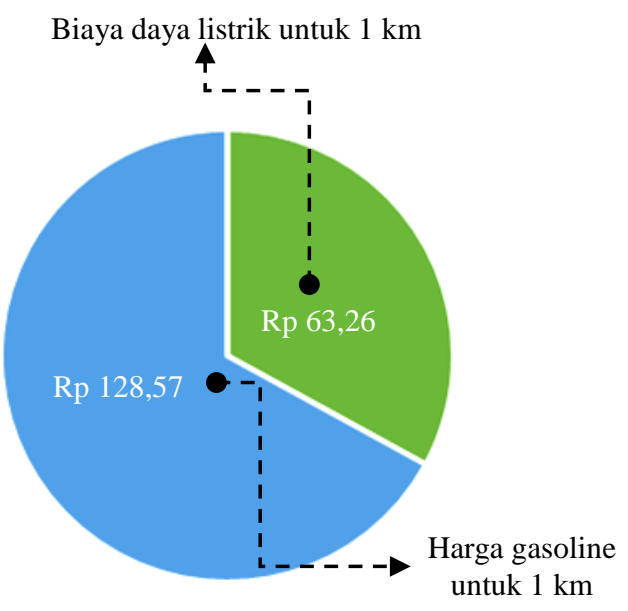

Gambar 12. Grafik perbandingan harga antara gasoline dan elektrik

Gambar 12 menunjukkan bahwa ada selisih harga gasoline dengan daya listrik per kilometernya yaitu sebesar Rp 65,31 (gasoline lebih mahal). Oleh karena itu dari sisi harga energi maka kendaraan listrik ini jauh lebih untung dibandingkan dengan kendaraan motor bakar. Emisi juga menjadi pertimbangan, di mana kendaraan listrik tidak berhubungan dengan gas buang atau yang sering disebut sebagai emisi zero. Seiring waktu dan juga pertambahan kendaraan bermotor bakar di tengah-tengah masyarakat maka polusi menjadi perhatian saat ini. Untuk mengurangi polusi tersebut maka kendaraan listrik yang dikenal dengan emisi zero merupakan salah satu solusi terbaik. Terkait dengan sepeda motor listrik beroda tiga yang dikhususkan pada penyandang cacat kaki ini adalah bahwa kendaraan ini lebih mudah untuk dirawat, tidak bising, dan tentu lebih hemat energi.

\section{KESIMPULAN}

Berdasarkan hasil penelitian maka dapat disimpulkan bahwa jarak maksimum yang dapat ditempuh sepeda motor listrik beroda tiga yang dibuat adalah 19,71 km yang dilakukan selama 2 jam 28 menit sampai daya listrik baterai habis. Biaya konsumsi listrik yang dibutuhkan sepeda ini sebanyak Rp 1.246,92 untuk menempuh 19,71 $\mathrm{km}$ tersebut, jika dibandingkan dengan sepeda motor (Vario 125 eSP) dengan spesifikasi konsumsi bahan bakar $59,5 \mathrm{~km} /$ liter (asumsi menggunakan pertalite Rp 7.650 tahun 2021) maka biaya yang dibutuhkan untuk menempuh 19,71 km adalah Rp 2.534,14. Supaya lebih mudah melihat perbedaan harga ini dapat ditampilkan pengeluaran per kilometernya, yaitu untuk menempuh jarak $1 \mathrm{~km}$ dibutuhkan biaya listrik sebesar Rp 63,26 sedangkan gasoline (pertalite) sebesar Rp 128,57. Dari segi bahan bakar atau konsumsi daya listrik maka kendaraan motor listrik lebih irit dibandingkan dengan sepeda motor bakar. Selain itu kendaraan listrik memiliki potensi yang besar untuk menjadi kendaraan yang lebih diminati oleh masyarakat karena tidak menghasilkan emisi, proses pembuatan yang relatif mudah, dan perawatan yang relatif murah.

Pengujian ini dilakukan pada kendaraan sepeda motor listrik beroda tiga yang dirancang dan dirakit sendiri dalam skala laboratorium. Tentunya produk ini adalah rancangan awal yang masih membutuhkan pengkajian lebih lanjut untuk menghasilkan produk yang lebih optimal. Diharapkan dengan adanya penelitian ini akan bermanfaat sebagai informasi ataupun sebagai bahan pertimbangan oleh pemangku kepentingan dalam menciptakan produk kendaraan listrik di tengah-tengah masyarakat.

\section{REFERENSI}

[1] A. Erow and F. Fadhillah, Pelaksanaan strategi dan rencana aksi pengendalian pencemaran udara DKI Jakarta, ICEL, 2019, p. 274.

[2] F. Ruhiat, D. Heryadi, and A. Akim, Strategi NGO lingkungan dalam menangani polusi udara di Jakarta (Greenpeace Indonesia), Andalas J. Int. Stud., vol. 8, no. 1, 2019, p. 16.

[3] G. Heryana et al., Plug in hybrid electric vehicle power consumption analysis in tropical area, AIP Conf. Proc., vol. 2230, issue 1, May 2020, p. 50001. DOI: $10.1063 / 5.0003756$.

[4] R. Siregar, M. Adhitya, D. A. Sumarsono, G. Heryana, F. Zainuri, and N. Nazaruddin, Study the brake performance of a passenger car based on the temperature that occurs in each brake unit, AIP Conf. Proc., vol. 2227, issue 1, May 2020, pp. 1-7. DOI: $10.1063 / 5.0003747$.

[5] N. Nurhadi, Pengembangan Sepeda motor listrik sebagai sarana transportasi, Seminar Nasional Inovasi dan Aplikasi Teknologi di Industri (SENIATI) 2018, Malang, 3 Februari 2018, pp. 249-255.

[6] D. Dahlan, E. Prasetyo, and D. Junkypri, Analisis konsumsi daya baterai lithium-ion pada sepeda motor listrik 1 (satu) kW, Seminar Rekayasa Teknologi (SemResTek), Jakarta, 15-16 Agustus 2018, pp. 306-312.

[7] Elinur, D. Priyarsono, M. Tambunan, and M. Firdaus, Perkembangan konsumsi dan penyediaan energi dalam perekonomian Indonesia, Indones. J. Agric. Econ., vol. 2, no. 1, 2010, pp. 19-38.

[8] A. F. Sa'adah, A. Fauzi, and B. Juanda, Peramalan penyediaan dan konsumsi bahan bakar minyak Indonesia dengan model sistem dinamik," J. Ekon. dan Pembang. Indones., vol. 17, no. 2, 2017, pp. 118-137.

[9] D. Braithwaite and I. Gerasimchuk, Selepas bahan bakar fosil: Transisi fiskal Indonesia, IISD, 2019.

[10] Ismiyati, D. Marlita, and D. Saidah, Pencemaran udara akibat emisi gas buang kendaraan bermotor," J. Manaj. Transp. Logistik, vol. 01, no. 03, 2014, pp. 241-248.

[11] R. A. Handika and Driejana, Polusi udara dalam rumah sekitar jalan raya: Intrusi no.2 dari transportasi dan gangguan pernapasan pada penghuni rumah, J. Dampak, vol. 10, no. 2, 2013, p. 119.

[12] N. S. Kumara, Tinjauan perkembangan kendaraan listrik dunia hingga sekarang, Transmisi, vol. 10, no. 2, 2008, pp. 89-96.

[13] G. E. Dieter and L. C. Schmidt, Engineering design, 5th ed., College Park: MC Graw Hill, 2013.

[14] R. Siregar, Korelasi besar temperatur pemanasan cetakan terhadap kualitas hasil press paving block berbahan dasar sampah plastik, FLYWHEEL J. Tek. Mesin Untirta, vol. V, no. 1, 2019, pp. 41-45.

[15] K. Deepak, R. Gowtham, T. Hariharan, S. Manimaran, and R. Seyezhai, Simulation and implementation of electric bicycle employing BLDC drive, Int. J. Adv. Res. Basic Eng. Sci. Technol., vol. 2, no. 10, 2016, pp. 2395-695.

[16] N. M. A. Wijaya, K. I. N. S., P. C. G. I., and Y. Divayana, Perkembangan baterai dan charger untuk mendukung pemasyarakatan sepeda listrik di Indonesia," SPEKTRUM, 
vol. 8, no. 1, February, 2021, pp. 15-26.

[17] B. Setiyawan, Rancang Bangun Sepeda Listrik, Surakarta: Jurusan Teknik Mesin Universitas Sebelas Maret, 2012.

[18] M. A. H. Ashari, A. Rusdinar, and P. Pangaribuan, Sistem monitoring dan manajemen baterai pada mobil listrik, $e$ Proceeding Eng., vol. 5, no. 3, 2018, pp. 4243-4248.

[19] R. M. Hamid, Rizky, M. Amin, and I. B. D, Rancang bangun charger baterai untuk kebutuhan UMKM, J. Teknol. Terpadu, vol. 4, no. 2, 2017, pp. 130-136.

[20] Ismail, Perancangan sepeda manual menjadi sepeda listrik menggunakan komponen penggerak motor listrik, baterai dan kontroler, Laporan tugas akhir program D3, UIN Alaudin Makassar, 2020.

[21] I. N. Sutantra and B. Sampurno, Teknologi otomotif. Surabaya: Penerbit Guna Widya, 2010.

[22] R. Siregar, Pengaruh persentase massa pasir terhadap tegangan tekan (compressive stress) pada grass block lubang lima berbahan sampah plastik, JTT (Jurnal Teknol. Terpadu), vol. 8, no. 1, 2020, pp. 51-55.

[23] S. Rolan, Perkiraan kekuatan struktur mekanik side scraper dengan metode elemen hingga beserta rekomendasi material pengganti elemen kritis, ROTASI, vol. 21, no. 4, 2019, pp. 251-257.

[24] Admin, Daftar Konsumsi BBM Sepeda Motor Honda, 2019. [Online]. Available:

https://www.hondacengkareng.com/daftar-konsumsi-bbmsepeda-motor-honda/comment-page-2/. [Accessed: 03Mar-2021].

[25] V. Ratriani, Cek, daftar tarif listrik PLN terbaru periode April-Juni 2021, 2021. [Online]. Available:

https://industri.kontan.co.id/news/cek-daftar-tarif-listrikpln-terbaru-periode-april-juni-2021. [Accessed: 10-Jun2021]. 